\title{
THE YIELD OF SILPHIUM PERFOLIATUM L. DEPENDING ON THE CONDITIONS OF CULTIVATION
}

\author{
Shalyuta B.V. ${ }^{*}$, Kostitskaya E.V. \\ Belarusian State Agricultural Academy, Gorki, Belarus \\ "Corresponding author: e-mail: a.sheliuta@mail.ru
}

\begin{tabular}{l}
\hline ARTICLE INFO \\
\hline Article history: \\
Received: December 2017 \\
Received in the revised form: \\
February 2018 \\
Accepted: April 2018 \\
\hline Key words: \\
Silphium perfoliatum, \\
seed yield, \\
seed, \\
seeding, \\
field germination
\end{tabular}

\begin{abstract}
The article presents the results of two-year studies on the influence of the method of sowing and the level of nitrogen application on the yield of seeds of Silphium perfoliatum L. - a new fodder crop for the conditions of Belarus. Silphium is precious for the nutritive value of green mass. According to the literature sources, dry matter contains $16-28 \%$ of protein, more than $60 \%$ of nitrogen-free extractives, $13-$ $23 \%$ of sugars, high content of mineral substances, a small amount of fiber, adequate calcium and phosphorus, carotene, vitamin C. Mineral composition of Silphium contains $17.6 \%$ of dry matter, including $152.3 \mathrm{mg} \cdot \mathrm{kg}^{-1}$ of ash. Macro elements: calcium -18.1 , phosphorus 2.55 , manganese -4.48 , potassium -24.03 , sodium -0.40 , sulphur $0.40 \mathrm{mg} \cdot \mathrm{kg}^{-1}$ of mg $\cdot \mathrm{kg}^{-1}$ of dry matter. The mass of 1000 seeds was from 23.7 to $25.5 \mathrm{~g}$. The seed germination was good and varied from $75 \%$ to $84 \%$. It has been established that the best way to sow the Silphium is planting seedlings according to the $70 \times 30$ scheme. This option ensured the yield of seeds of 3.6 and $3.7 \mathrm{c} / \mathrm{ha}$. The applying of increased doses of nitrogen fertilizers $\mathrm{N}_{90}$ and $\mathrm{N}_{120}$ and sowing seeds ensured the yield of seeds ranging from 3,6 to $3,9 \mathrm{c} \cdot \mathrm{ha}^{-1}$.
\end{abstract}

\section{Введение}

Увеличение производства кормов возможно при повышении продуктивности посевов и эффективном использовании имеющихся ресурсов, включая малопригодные земли. Необходимо вводить крупнотравные виды, посевы которых обеспечивают получение высокого урожая, отдавая приоритет малозатратным технологиям, обращая внимание на продуктивность растения, качество зеленой массы, биологические и хозяйственные достоинства культуры. Интродукция экологически стойких видов имеет важное производственное значение для земледелия лесной зоны.

Среди перспективных кормовых растений многими учеными России, Украины и других стран изучено сильфия пронзеннолистная (Silphium Perfoliatum L.) (Абрамов, 1992; Асемкулова, 2011; Емелин, 2008a,b). Это одна из самых урожайных кормовых культур. Она способна давать высокий урожай зеленой массы в зоне с количеством выпадения осадков до 500 мм и более $-1500-1600$ ц·га ${ }^{-1}$. На орошаемых землях южной зоны свыше 2300 ц·га ${ }^{-1}$. Впервые это растение попало на белорусскую почву 
- в Центральный Ботанический сад АН БССР - в 1963г, немного семян было получено из Черновиц от З.И. Грицака (Емелин, 2008b).

Сильфия пронзеннолистная - кормовая культура высокой хозяйственной ценности. Она классифицируется в группе кормовых культур сенажно-силосного направления и характеризуется высокой продуктивностью посевов, повышенным содержанием белка и отзывчивостью на удобрения. По экологической пластичности и долголетию (до15 лет и более) произрастания на одном месте у сильфии нет равных. По урожаю биомассы сильфия одна из самых урожайных кормовых культур. Она способна давать урожай зеленой массы в зонах с выпадением осадков до 500 мм и более - 1500-1600 ц·га $\mathrm{a}^{-1}$, на орошаемых землях южной зоны - до 2369 ц·га ${ }^{-1}$ Сильфия пронзеннолистная в различных районах выращивания превосходит по своей продуктивности кукурузу, многолетние травы, подсолнечник и другие кормовые культуры в 1,5-2 раза. Она может занимать большой удельный вес в структуре силосных культур (Емелин, 2011).

Сильфия имеет ценную по питательности зеленую массу. В сухом веществе содержится 16-28\% протеина, более $60 \%$ БЭВ, 13-23\% сахаров, высоко содержание в ней зольных веществ, небольшое количество клетчатки, достаточное количество кальция и фосфора, каротин, витамин С. Минеральный состав сильфии, содержит 17,6\% сухого вещества, включая золы 152,3 мг/кг. Макроэлементы: кальций - 18,1, фосфор - 2,55, магний - 4,48, калий $-24,03$, натрий $-0,40$, сера $-0,40$ мг·кг ${ }^{-1}$ сухого вещества. Микроэлементы: железо - 128,02, медь - 7,5, цинк - 6,25, кобальт - 0,45 мг'кГ ${ }^{-1}$ сухого вещества (Кошелев, 1993).

На практике большое значение имеют биологические и хозяйственные возможности вида при размножении. Морфология генеративных органов растений сильфии имеет свои особенности. Плод - плоская семянка удлиненно- сердцевидной формы, серовато-коричневая. Созревание семян идет долго и неравномерно. Сначала созревают семена нижних корзинок, затем постепенно созревание переходит к верхним корзинкам, т.е. от соцветия 1-ого порядка к соцветиям 2-ого порядка и т.д. В то время как в нижних корзинках плоды уже созрели, средние корзинки цветут, а верхние находятся еще в фазе бутонизации.

\section{Цель и задачи исследований}

Целью наших исследований явилось установить особенности формирования и созревания семян в конкретных почвенно-климатических условиях. Задачей исследований было определить влияние способа посева и уровня азотного питания на урожайность семян и их посевные качества.

\section{Объектом исследований}

явился сорт сильфии пронзеннолистной венгерской селекции Овари гигант. 
The yield of silphium...

\section{Методики проведения исследований}

1. Количество всходов и выживаемость определяется через 30 дней со дня посева и перед уходом в зиму путем подсчета растений на постоянных площадках $0,25 \mathrm{~m}^{2}$ в четырёхкратном повторении (Методика, 1971).

2. Фенологические наблюдения за сроками наступления очередных фаз развития проводятся визуально. Началом наступления очередной фазы развития считается наступление ее у 10 \% растений, а полная фаза отмечается при наступлении ее у $75 \%$ растений на делянках (Методика, 1971).

3. Масса 1000 семян. Семена основной культуры тщательно перемешивают, отсчитывают без выбора две пробы по 500 шт. и взвешивают их до сотой доли грамма. Вычисляют фактическое расхождение между результатами взвешивания двух проб и сравнивают с допустимым расхождением, которое определяют по таблице допустимых расхождений (Семена сельскохозяйственных культур, 2011a).

4. Из семян основной культуры, выделенных из навесок при определении чистоты по ГОСТ 12037, отбирают четыре пробы по 100 семян в каждой. Сильфию проращивают на песке и между бумагой.

Проращивание семян между бумагой (МБ). Семена раскладывают в растильнях между слоями увлажненной фильтровальной бумаги: два-три слоя на дне растильни, одним слоем прикрывают семена.

Проращивание семян на песке (НП). Растильни на 2/3 их высоты наполняют увлажненным песком и разравнивают. Затем раскладывают семена и трамбовкой вдавливают в песок на глубину, равную их толщине. Энергию прорастания определяют на 10 сутки, всхожесть на 21 день, при переменной температуре $10-30^{\circ} \mathrm{C}$ (Семена сельскохозяйственных культур, 2011b).

\section{Основная часть}

Исследования проводились на опытном поле «Тушково» УО БГСХА. Почва опытного участка является типичной для северо-восточного региона РБ. Агротехнические показатели подпахотного 20-40 и пахотного 0-20 см слоя почвы следующие: $\mathrm{pH}$ в KCL 6,0-6,6, гидролитическая кислотность 1,17-0,86 мг. - экв. на 100 г почвы, степень насыщенности основаниями 91-96\%, содержание гумуса (по Тюрину) 0,73-1,65\%, подвижных соединений $\mathrm{P}_{2} \mathrm{O}_{5}-97-181$ мг и $\mathrm{K}_{2} \mathrm{O}-164-192$ мг на 1 кг почвы.

Опыт семенами был заложен 26 мая 2015 г. в 4-х кратной повторности с нормой высева 70 тыс. Растений·га ${ }^{-1}$, с учетной площадью делянки $10 \mathrm{~m}^{2}$. Опыт рассадой заложен 1 июля 2015 г. в 4-кратной повторности, по следующим схемам опыта: 70x30, 70x50, 70x70. Посадку сильфии пронзеннолистной проводили вручную согласно схеме опыта. Посев проводился без покрова широкорядным способом.

Оптимальным сроком уборки семян сильфии является пожелтение до 75\% корзинок третьего порядка. Наиболее полноценные семена для посева формируются на соцветиях первых 3-4 порядков. Поэтому их лучше убирать вручную, остальную часть корзинок по мере созревания убирают зерновым комбайном на высоком срезе. 
Shalyuta B.V., Kostitskaya E.V.

На рисунке 1 представлены семена сильфии пронзеннолистной полученные в наших исследованиях с венгерского сорта Овари гигант.

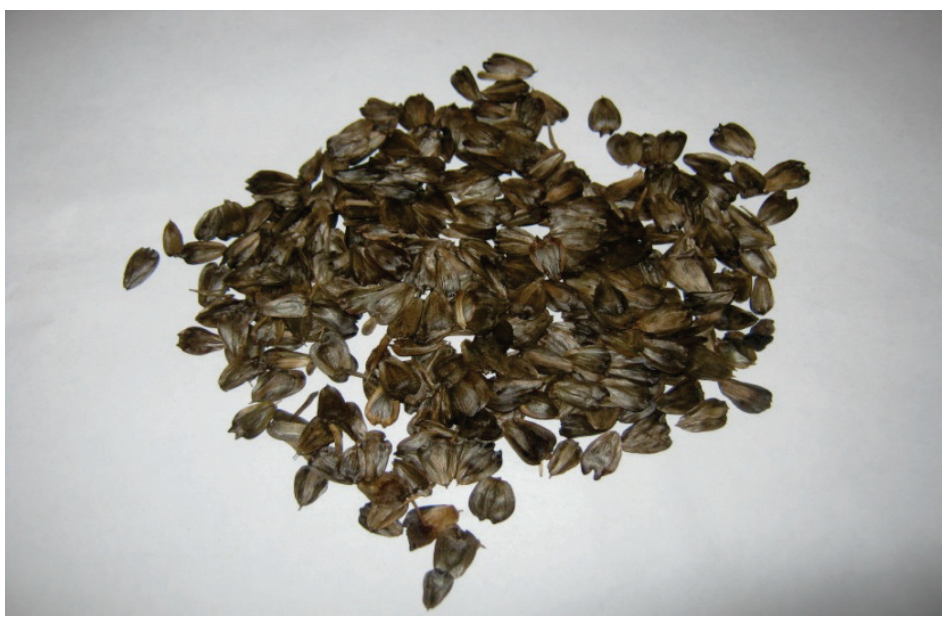

Рисунок 1. Семена сильфии пронзеннолистной, 20172.

Условия возделывания оказали существенное влияние на семенную продуктивность сильфии пронзеннолистной. Из данных, представленных в таблице 1 видно, что за 2 года пользования урожайность семян сильфии составила от 2,7 до 3,7 ц·га ${ }^{-1}$. Наибольшую урожайность сформировали растения посаженные рассадой, их урожайность превышала 3,0 ц·га ${ }^{-1}$, в то время как урожайность семян полученных с культуры высаженной семенами составляла 2,7 ц· га ${ }^{-1}$.

Наиболее высокая урожайность семян 3,6 и 3,7 ц/га получена при посадке рассадой по схеме 70х30, что превышает посев семенами на 0,9-1 ц/га.

По литературным данным в основном масса 1000 семян составляет 18-20 г, у вариантов нашего опыта масса колебалась от 23,7 до 25,3 г., что возможно связано с сортовыми особенностями культуры (венгерский сорт Овари гигант).

Таблица 1.

Урожайность и посевные качества семян в зависимости от способов посева, изга

\begin{tabular}{|c|c|c|c|c|}
\hline \multirow[t]{2}{*}{ Варианты } & \multicolumn{2}{|c|}{$\begin{array}{c}\text { Урожайность семян, } \\
\text { Ц·га }\end{array}$} & \multicolumn{2}{|c|}{$\begin{array}{c}\text { Мacca } 1000 \text { семян, } \\
\Gamma \\
\end{array}$} \\
\hline & $2016 \Gamma$. & 2017 г. & $2016 \Gamma$. & 2017 г. \\
\hline Семена & 2,7 & 2,7 & 23,9 & 23,7 \\
\hline Посадка рассадой & & & & \\
\hline $70 \times 30$ & 3,6 & 3,7 & 25,2 & 25,3 \\
\hline $70 \times 50$ & 3,2 & 3,3 & 24,8 & 24,6 \\
\hline $70 \times 70$ & 3,0 & 3,0 & 24,1 & 24,0 \\
\hline среднее & 3,1 & 3,2 & 24,5 & 24,4 \\
\hline $\mathrm{HCP}_{05}$ & 0,22 & 0,25 & & \\
\hline
\end{tabular}


The yield of silphium...

Что касается энергии прорастания и всхожести (Таблица 2.), то у растений выращенных их семян в 2016 году она составила 48\% и 69\%, что ниже по сравнению с рассадой, где они составили от 57 до $59 \%$ и от 75 до 78\% соответственно. В 2017 году показатели энергии прорастания и всхожести были выше, так, энергия прорастания, которая определялась на 10 сутки, составляла от 54\% (семена) до 63 \% (рассада). Всхожесть семян также была значительно лучше по сравнению с 2016 годом и варьировала от $75 \%$ (семена) до $82 \%$ (рассада).

Таблица 2.

Показатели энергии прорастания и всхожести растений в зависимости от способа посева, \%

\begin{tabular}{|c|c|c|c|c|}
\hline \multirow[t]{2}{*}{ Варианты } & \multicolumn{2}{|c|}{$\begin{array}{c}\text { Энергия прорастания, } \\
(\%) \\
\end{array}$} & \multicolumn{2}{|c|}{$\begin{array}{c}\text { Всхожесть, } \\
(\%)\end{array}$} \\
\hline & 2016 & 2017 & 2016 & 2017 \\
\hline Семена & 48 & 54 & 69 & 75 \\
\hline $70 \times 30$ & 59 & 63 & 78 & 82 \\
\hline $70 \times 50$ & 58 & 63 & 76 & 82 \\
\hline $70 \times 70$ & 57 & 62 & 75 & 80 \\
\hline Среднее & 56 & 61 & 75 & 80 \\
\hline
\end{tabular}

В опыте с применением минеральных удобрений (Таблица 3) урожайность семян возрастала по мере увеличения доз азотного удобрения от 2,9 (Фон) до 3,9 ц·га $\left(\right.$ Фон $\left.+\mathrm{N}_{120}\right)$. Наиболее высокая урожайность семян от 3,6 до 3,9 ц·га ${ }^{-1}$ была получена в варианте с внесением повышенных норм азотных удобрений $\mathrm{N}_{90}$ и $\mathrm{N}_{120}$.

Таблица 3.

Урожайность и посевные качества семян при разных дозах азотного удобрения, $u \cdot 2 a^{-1}$

\begin{tabular}{|c|c|c|c|c|}
\hline \multirow{2}{*}{ Варианты } & \multicolumn{2}{|c|}{$\begin{array}{c}\text { Урожайность семян, } \\
\left(ц \cdot \mathrm{ra}^{-1}\right)\end{array}$} & \multicolumn{2}{|c|}{$\begin{array}{l}\text { Macca } 1000 \text { семян, } \\
(г)\end{array}$} \\
\hline & 2016г. & $2017 \Gamma$. & $2016 \Gamma$. & 2017 г. \\
\hline $\mathrm{P}_{60} \mathrm{~K}_{90}($ фон $)-$ & 2,9 & 3,0 & 24,7 & 24,5 \\
\hline$\Phi \mathrm{OH}+\mathrm{N}_{30}$ & 3,1 & 3,1 & 24,9 & 24,6 \\
\hline$\Phi \mathrm{OH}+\mathrm{N}_{60}$ & 3,3 & 3,4 & 25,1 & 25,0 \\
\hline$\Phi \mathrm{OH}+N_{90}$ & 3,6 & 3,8 & 25,3 & 25,1 \\
\hline$\Phi \mathrm{OH}+\mathrm{N}_{120}$ & 3,7 & 3,9 & 25,5 & 25,1 \\
\hline $\mathrm{HCP}_{05}$ & 0,12 & 0,14 & & 24,9 \\
\hline
\end{tabular}

Посевные качества также показывали лучшие результаты при применении повышенных доз удобрения. Так, масса 1000 семян изменялась от 24,5 до 25,5г.

Энергия прорастания (Таблица 4.) составила в 2016 году от 50\% (Фон) до 59\% (Фон+N120), а лабораторная всхожесть от 72 до 78\%. В 2017 году посевные качества растений были выше, показатель энергии прорастания колебался от 54\% (фон) до $63 \%$ на фоне $\mathrm{N}_{120}$, всхожести - от 77 до $84 \%$. 
Shalyuta B.V., Kostitskaya E.V.

Таблица 4.

Показатели энергии прорастания и всхожести растений при разных дозах азотного удобрения, \%

\begin{tabular}{|c|c|c|c|c|}
\hline \multirow[t]{2}{*}{ Варианты } & \multicolumn{2}{|c|}{$\begin{array}{c}\text { Энергия прорастания, } \\
\text { (\%) }\end{array}$} & \multicolumn{2}{|c|}{$\begin{array}{l}\text { Всхожесть, } \\
(\%)\end{array}$} \\
\hline & 2016 & 2017 & 2016 & 2017 \\
\hline $\mathrm{P}_{60} \mathrm{~K}_{90}($ фон $)-$ & 50 & 54 & 72 & 77 \\
\hline$\Phi$ он $+\mathrm{N}_{30}$ & 53 & 58 & 74 & 80 \\
\hline$\Phi \mathrm{OH}+\mathrm{N}_{60}$ & 57 & 61 & 76 & 81 \\
\hline$\Phi \mathrm{OH}+N_{90}$ & 58 & 61 & 78 & 81 \\
\hline$\Phi \mathrm{OH}+\mathrm{N}_{120}$ & 59 & 63 & 78 & 84 \\
\hline
\end{tabular}

\section{Заключение}

Сильфия пронзеннолистная является перспективной кормовой культурой для условий Беларуси и обладает высокой продуктивной урожайностью семян.

Урожайность семян сильфии пронзеннолистной зависела от способа посева и доз внесения азотных удобрений. Наиболее высокая урожайность 3,6 и 3,7 ц·га сформирована при посадке растений рассадой по схеме 70х30.

Внесение повышенных доз азотных удобрений $\mathrm{N}_{90}$ и $\mathrm{N}_{120}$ при посеве ее семенами обеспечило урожайность семян от 3,6 до 3,9 ц·га ${ }^{-1}$.

Масса 1000 семян составила от 23,7 до 25,5 г. Всхожесть семян была хорошей и варьировала от $75 \%$ до $84 \%$.

\section{Список использованных источников}

Abramov, A. А. (1992). Сильфия пронзеннолистная в кормопроизводстве: АН Украиньл. Центральный ботанический сад им. Н.Н. Гришко. А. А. Абрамов. - Киев: Наукова думка, 155.

Asemkulova, G.B. (2011). Влияние приемов воздельвания на урожайность нетрадиционных кормовых культур в условиях юго-востока Казахстана. Г. Б. Асемкулова // Кормопроизводство. - М., № 11, 37-39.

Emelin, V.A. (2008а). Даты наступления укосной спелости культуры, питательная иенность и продуктивность сильфии пронзеннолистной в зависимости от фаз развитии /В.А. Емелин.-Витебск: ВГАВМ, 74.

Emelin, V.A. (2008b). Сильфия пронзеннолистная в условиях Витебской области / В.А. Емелин // Земляробства і аховараслін, № 4, 64-67.

Emelin, V.A. (2011). Урожай зеленой массы и сроки использования сильфии пронзеннолистной в системе зеленого и сырьевого конвейерного кормопроизводства / В.А. Емелин // Земляробства і аховараслін, № 3, 12-14.

Koshelev, V.I. (1993). Использование зеленой массы сильфии пронзеннолистной в системе зеленого конвейера при откорме крупного рогатого скота. В.И. Кошелев, Н.Я. Попов, К.А. Варламова // Материалы 8-го Всероссийского сим - позиума по новым кормовым растениям. - Сыктывкар, 85-86.

Методика полевых опытов с кормовыми культурами. (1971). Всесоюзн. научноисслед. ин-т кормов им. В.Р. Вильямса, 158. 
The yield of silphium...

Семена сельскохозяйственных культур. (2011a). Методы определения массы 1000 семян: ГОСТ 12042-80.Измен.31.08.2011. Семена сельскохозяйственных культур. Методы определения массы 1000 семян. Минск. Министерство сельского хозяйства, 4.

Семена сельскохозяйственных культур. (2011b). Методы определения всхожести: ГОСТ 12038-84.Измен. 31.08.2011. - Семена сельскохозяйственных культур. Методы определения всхожести. - Минск. Министерство сельского хозяйства, 64.

\section{PLONOWANIE ROŻNIKA PRZEROŚNIĘTEGO SILPHIUM PERFOLIATUM L. W ZALEŻNOŚCI OD WARUNKÓW UPRAWY}

Streszczenie. Artykuł przedstawia wyniki dwuletnich badań nad wpływem metody wysiewu i poziomu zastosowania azotanu na plonowanie nasion rożnika przerośniętego (Silphium perfoliatum L.) - nowej rośliny paszowej w warunkach panujących na terenie Białorusi. Rożnik jest cenną roślina ze względu na wartości odżywcze zielonej masy. Według dostępnych źródeł, sucha masa zawiera 16-28\% białka, więcej niż 60\% związków bezazotowych wyciągowych, 12-23\% cukrów, wysoką zawartość substancji mineralnych, małą ilość błonnika, taką samą ilość wapna i fosforu, karotenu, witaminy C. Rożnik w swoim składzie mineralnym zawiera $17.6 \%$ suchej masy, w tym $152.3 \mathrm{mg} \cdot \mathrm{kg}$ popiołu. Makro pierwiastki: wapń -18.1 , fosfor -2.55 , mangan 4.48, potas -24.03 , sód 0.40 , siarka $-0.40 \mathrm{mg} \cdot \mathrm{kg}^{-1}$ na $\mathrm{mg} \cdot \mathrm{kg}^{-1}$ suchej masy. Waga 1000 nasion wynosiła od 23.7 do $25.5 \mathrm{~g}$. Kiełkowanie nasion było dobre i wynosiło of $75 \%$ do $84 \%$. Ustalono, że najlepszym sposobem wysiewu rożnika jest sadzenie sadzonek zgodnie ze schematem 70x30. Ten wariant zapewniał plon nasion wynoszacy 3.6 i $3.7 \mathrm{c} \cdot \mathrm{ha}^{-1}$. Zastosowanie zwiększonych dawek nawozów azotowych $\mathrm{N}_{90}$ i $\mathrm{N}_{120}$ oraz wysiew nasion zapewniły plon nasion od 3.6 do $3.9 \mathrm{c} \cdot \mathrm{ha}^{-1}$.

Słowa kluczowe: Rożnik przerośnięty, plon nasion, nasiona, siew, kiełkowanie, waga 1000 nasion 